\title{
An Analysis of The Asymmetric Effects of Natural Gas Consumption on Economic Growth in Pakistan: A Non-linear Autoregressive Distributed Lag Approach
}

\section{Hafiz M. Sohail}

South China Normal University School of Economics and Management

Zengfu Li ( $\sim$ lizengfu@scnu.edu.cn )

South China Normal University School of Economics and Management

Muntasir Murshed

North South University

Alvarado Rafael

Universidad Nacional de Loja

Haider Mahmood

Prince Sattam bin Abdulaziz University

\section{Research Article}

Keywords: economic progress, natural gas, NARDL, financial development, Pakistan, causality

Posted Date: July 13th, 2021

DOI: https://doi.org/10.21203/rs.3.rs-617980/v1

License: (c) (1) This work is licensed under a Creative Commons Attribution 4.0 International License.

Read Full License

Version of Record: A version of this preprint was published at Environmental Science and Pollution Research on August 23rd, 2021. See the published version at https://doi.org/10.1007/s11356-021-159879. 


\title{
An analysis of the asymmetric effects of natural gas consumption on economic growth in Pakistan: A non-linear autoregressive distributed lag approach
}

\author{
Hafiz M.Sohail ${ }^{1}$ \\ ${ }^{1}$ School of Economics \& Management, South China Normal University, Guangzhou 510631, China \\ Email: hms@m.scnu.edu.cn \\ Orcid: https://orcid.org/0000-0002-7885-5549
}

\author{
Zengfu $\mathbf{L i}^{2, *}$ \\ ${ }^{2}$ School of Economics \& Management, South China Normal University, Guangzhou 510631, \\ China \\ * Corresponding author's Email: lizengfu@ @scnu.edu.cn \\ Orcid: https://orcid.org/0000-0002-6118-0952
}

\author{
Muntasir Murshed ${ }^{3}$ \\ ${ }^{3}$ School of Business and Economics, North South University, Dhaka-1229, Bangladesh \\ Email: muntasir.murshed@northsouth.edu \\ Orcid: https://orcid.org/0000-0001-9872-8742
}

\author{
Alvarado Rafael ${ }^{4}$ \\ ${ }^{4}$ Carrera de Economia and Centro de InvestigacionesSociales y Economicas, Universidad \\ Nacional de Loja, Loja 110150, Ecuador \\ Email: jose.r.alvarado@unl.edu.ec \\ Haider Mahmood ${ }^{5}$ \\ ${ }^{5}$ Department of Finance, College of Business Administration, Prince Sattam Bin Abdulaziz \\ University, 173, Alkharj 11942, Saudi Arabia \\ Email: haidermahmood@hotmail.com
}

\begin{abstract}
Natural gas is an important energy resource that is used to produce the national output of Pakistan.On the other hand, since natural gas is a relatively cleaner energy resource compared to oil and coal, enhancing the level of natural gas use is believed to improve the environmental quality in Pakistan which, in turn, can be expected to enable the nation to sustain its economic performances. Hence, it is pertinent to assess the effects of natural gas consumption on the nation's economic growth level.The main objective of this paper was to explore the asymmetric effects of natural gas consumption, controlling for financial development, on Pakistan's economic growth level over the 1965-2019 period. The results from the Augmented Dickey-Fuller, Phillips-Perron, and Zivot-Andrews unit root tests confirmed a mixed order of integration among the variables. Besides, the bounds test and Gregory-Hansen cointegration analysis revealed evidence of long-run associations between economic growth, natural gas consumption, and financial development. Moreover, the outcomes from the non-linear autoregressive distributed lag model showed thatin the short-run positive changes in the natural gas consumption levels increase economic growth in Pakistan. On the other hand, in the long-run, positive and negative changes in natural gas consumption levels increase and decrease the economic growth level, respectively, in the long-run. On the other hand, both positive and negative changes in the financial development level are found to reduce the economic growth level in the long-run.
\end{abstract}


Furthermore, the Hacker-Hatemi-J causality analysis verifiedthat natural gas consumption influences the economic growth level in Pakistan; thus, the energy consumption-led growth phenomenon was unearthed. In line with these key findings, several policy level suggestions are put forward for Pakistan to boost its natural gas consumption figures in order to enhance its economic growth level in the future.

Keywords:economic progress; natural gas; NARDL; financial development; Pakistan; causality

\section{Introduction}

Energy supply is one of the critically important factors of production in the contemporary era (Rehman et al., 2018; Magazzino et al., 2021). Although coal and oil are the major fossil fuels used globally, the environmental complications associated with the combustion of these energy resources have motivated world economies to look for relatively cleaner alternatives (Irfan et al., 2020). In this regard, mitigating fossil fuel dependency to promote greater use of non-fossil fuels utilization for producing output has been recommended in several studies (Hussain\&Rehman, 2021; Rehman et al., 2019a). However, the adoption of cleaner energy resources is often inhibited due to various macroeconomic constraints experienced by the developing nation, in particular (Irfan et al., 2021; Xue et al., 2021; Nathaniel et al., 2021). Under such circumstances, the global economies have preferred to employ relatively cleaner fossil fuels to generate the national outputs. Consequently, several of the world economies have turned to natural gas as an alternative to the traditionally consumed fossil fuels which are comparatively harmful to the environment (Dong et al., 2018; Xu\& Lin, 2019). As a result, natural gas hasbecome an essential feature of the international energy mixesand is widely used for residential (Rehman et al., 2020a), commercial (Rehman\&Deyuan, 2018a), andfarming (Chandio et al., 2019) purposes. Besides, natural gas is also used for electricity generation purposes (Rehman\&Deyuan, 2018b). It is an excellent electricity production option due to its adequate thermal productivity and low capital expenses(Apergis \& Payne, 2010).

Natural gas, like most other fossil fuels, contains hydrocarbon and therefore combustion of natural gas emits greenhouse gases $(\mathrm{GHG})$ into the atmosphere. Although utilization of unprocessed natural gas stimulates the emissions of large volumes of carbon dioxide (CO2) and other GHG, combustion of dry natural gas releases relatively less amount of such gases into the atmosphere.This is because, before the delivery of dry natural gas, the hazardous components of unprocessed natural gases are extracted. Hence, compared to oil and coal, natural gas can be considered a low carbon intensity fossil fuel.It is believed that natural gas combustion releases approximately halfthe amount of $\mathrm{CO} 2$ released from burning coal for generating electricity(Banks, 2003). Consequently, several of the world economies are currently pursuing policies to improve their natural gas consumption levels to reduce their energy consumption-induced GHG emissions in order to comply with their commitments under the Paris Agreement and the Sustainable Development Goals (SDG) agenda of the United Nations (Percebois, 2008; Apergis \& Payne, 2010).Besides, since GHG emissions have been acknowledged to hamper economic growth (Rehman et al., 2021), it is pertinent to consume relatively cleaner energy resources to simultaneously ensure economic and environmental well-being (Rehman et al., 2021).

Since all energy resources are not homogenously composed, their overall impacts on output can be expected to vary as well. However, overlooking the possible heterogeneity of the growth impacts associated with uses of different energy sources, the existing studies in the literature traditionally scrutinized the causal associations between aggregate energy use and gross domestic product(Ozturk, 2010; Payne, 2010).But, assessing the cumulative energy use-economic growth relationship may not account for the different impacts related to different kinds of energy resources consumed by the end-users and within the economic sectors(Payne, 2010). Moreover, it may also lead to erroneous strategy implications for each energy resource( Siddiqui, 2004; Payne, 2010).Hence, it is pertinent to conduct disaggregated analyses to explore the dissimilar impacts of different energy sources on economic growth (Lee \& Chang, 2005; Ozturk, 2010; Solarin \& Shahbaz, 2013). 
Although a significant proportion of the existing studies have scrutinized the total energy consumption-economic growth nexus, empirical workson the impacts of natural gas use on economic growth are minimal. Against this backdrop, this study aims to evaluate the natural gas consumption-economic growth nexus, controlling for financial development, in the context of Pakistan using annual frequency data spanning from 1965 to 2019. Traditionally, Pakistan has been largely been fossil fuel-dependent (Irfan et al., 2020b). In Pakistan, 47\% of primary energy demand is fulfilled by natural gas and is considered the primary fuel. Since 2000, both petroleum and natural gas have collectively functioned as primary energy inputs for the power plants in Pakistan (Shahbaz, et al., 2013). Figure 1 illustrates the trends in the shares of different energy resources in Pakistan's aggregate electricity output figures. However, following the increasing oil prices in the international markets, oil consumption in Pakistan is on the decline, especially due to the transport sector gradually transitioning from being petroleum-intensive to natural gasintensive. Besides, the government of Pakistan also promotes the use of compressed and liquefied natural gaseswithin the power and transport sectors; these two sectors account for about $51 \%$ and $40 \%$ of overall natural gas usage, respectively (Shahbaz et al., 2013). Hence, it can be hypothesized that natural gas consumption does play a critically important role in determining the growth of the Pakistan economy. Hence, the objective of this study is to unearth relevant economic growth policies for Pakistan in order to enable the nation to sustain its macroeconomic achievements in the future.

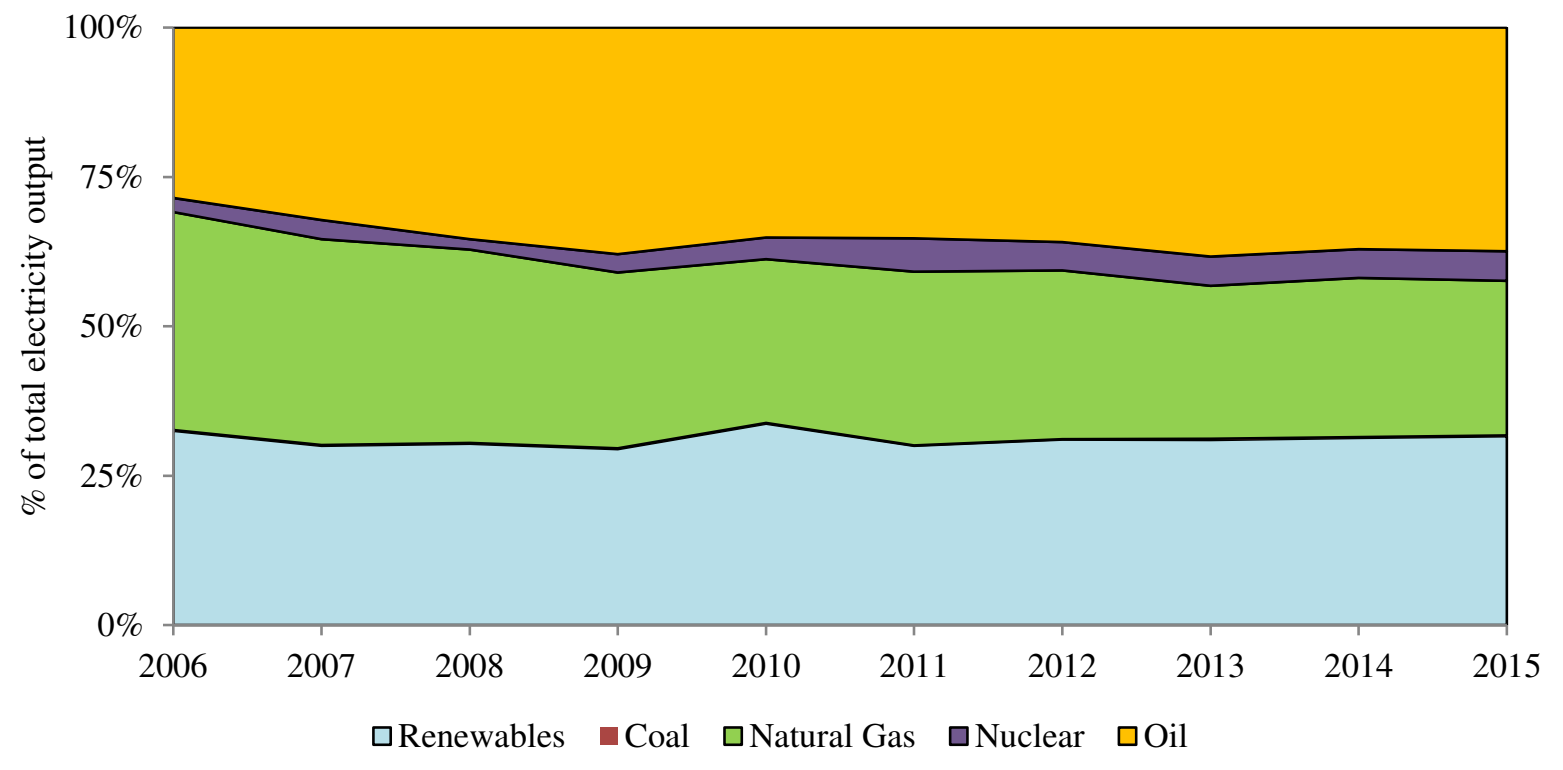

Figure 1: The trends in Pakistan electricity outputs generated using different energy sources Note: Renewables contain both hydroelectricity and other renewables Source: World Development Indicators (World Bank, 2020)

This current study contributes to the energy consumption-economic growth narrative for the case of Pakistan in several ways. Firstly, the existing studies that have explored the impacts of energy consumption on Pakistan's economic growth have used the conventional linear modeling methods which specifically evaluated the impacts of positive shocks to energy consumption on the nation's GDP level (Rehman et al., 2019b; 2020b).However, it is believed that the non-linear asymmetric techniques have more predictive control than the linear symmetric techniques (Melike et al., 2015). Hence, this study addresses this issue by using the nonlinear auto-regressive distributed lag (NARDL)method to model the energy use-economic growth nexus in Pakistan. It is asserted in the literature that the NARDL model is superior to the conventionally used auto-regressive distributed lag (ARDL) 
model since it predicts the effects of both positive and negative shocks to the explanatory variable on the outcome variable(Neog \& Yadava, 2020; Rehman et al., 2021).Furthermore, the NARDL technique is also believed to account for the short-run volatilities and structural break issues in the data. Secondly, the literature is overwhelmingly saturated with studies that have probed into the overall impacts of energy use on the Pakistan economy (Latief\&Lefen, 2019; Abbasi et al., 2021). In contrast, only a few of the preceding studies have used the NARDL method to isolate the heterogeneous effects of different energy resources, natural gas in particular, on Pakistan's economic growth indicators. Lastly, this study controls for structural break issues in the data within the analysis to safeguard the unbiasedness of the outcomes. The majority of the previous studies have overlooked the structural break concerns and therefore the evidence documented can be presumed to be inefficient and biased to some extent. In this regard, this study addresses this issue by firstly using the second-generation unit root and cointegration methods to ascertain the stationarity and cointegration properties of the variables of concern. Besides, the application of the NARDL method further neutralizes the structural break impacts within the short-and long-run elasticity estimation processes.

The rest of the manuscript is prepared as follows.Section 2 provides an outline of the trends in Pakistan's economic growth, natural gas consumption, and financial development. The previous relevant studies in the literature are then summarized in section 3. Section 4 explains the methodology used while section 5 reports the empirical results obtained from the analysis. Finally, section 6 concludes by recommending key policies as per the results found in this study.

\section{An overview of Pakistan's economic growth, natural gas use, and financial development}

The trends in Pakistan's annual GDP per capita and natural gas consumption figures are illustrated in Figure 2.Referring to economic growth, Pakistan is a lower-middle-income South Asian nation. It can be seen that the GDP per capita of Pakistan has, by and large, progresses steadily over the 1965-2019 period. Until 1996, the economy of Pakistan was growing steadily after which the GDP per capita figures somewhat declined and stagnated. However, from 2020 onward, the GDP per capita figures surged again implicating that the nation's economic reforms in the early 2000s managed to uplift the economic conditions to a large extent.As far as the natural gas consumption trends are concerned, the trends implicate that much like the nation's progressive trend in GDP per capita, Pakistan's natural gas consumption also depicts a rising trend. However, during the 1965-1988 period, the average annual growth rate of the natural gas consumption figures was relatively lower than the corresponding average growth rate of GDP per capita. Nevertheless, from 1999 onwards, the average trends in the growth rate of both these figures started to converge which gives the impression that utilization of natural gas in Pakistan does play a central role in determining its economic progress. 


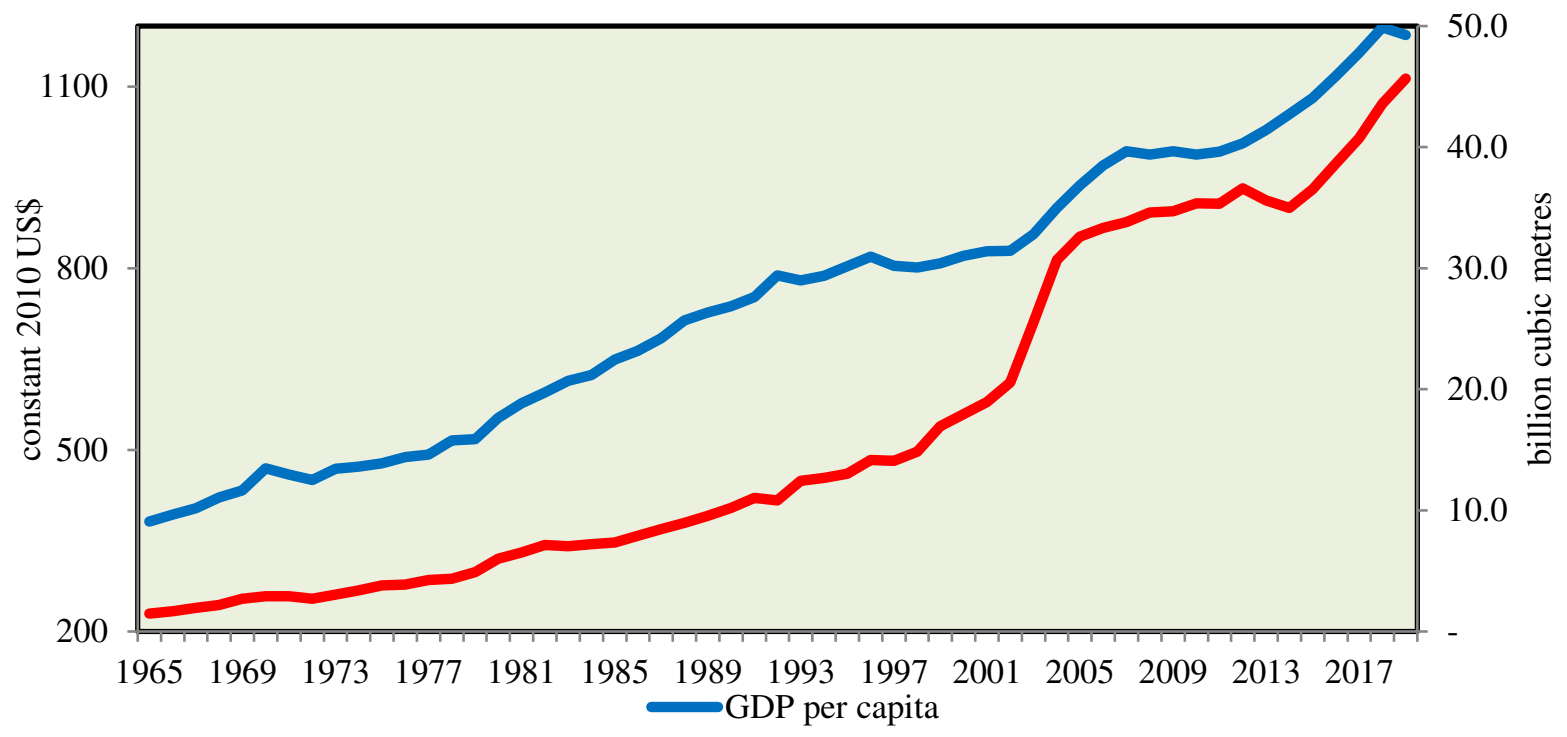

Figure 2: Trends in GDP per capita and natural gas consumption (1965-2019)

Source: World Development Indicators (World Bank 2020)

On the other hand, since our analysis also controls for financial development within the Pakistan economy, it is pertinent to have an understanding of the financial development trends as well. The level of financial development within an economy is often measured in terms of the percentage share of the value of domestic credit extended to the private sector in the GDP ( $\mathrm{Li}$ et al., 2021). Figure 3 illustrates the trends in Pakistan's financial development and annual GDP per capita figures. It can be seen that financial development in Pakistan has more or less matched the corresponding trends in the nation's GDP per capita since both the line graphs depict similar movements. Hence, it can be hypothesized that financial development, much like natural gas consumption, does influence the growth rate of the Pakistani economy.

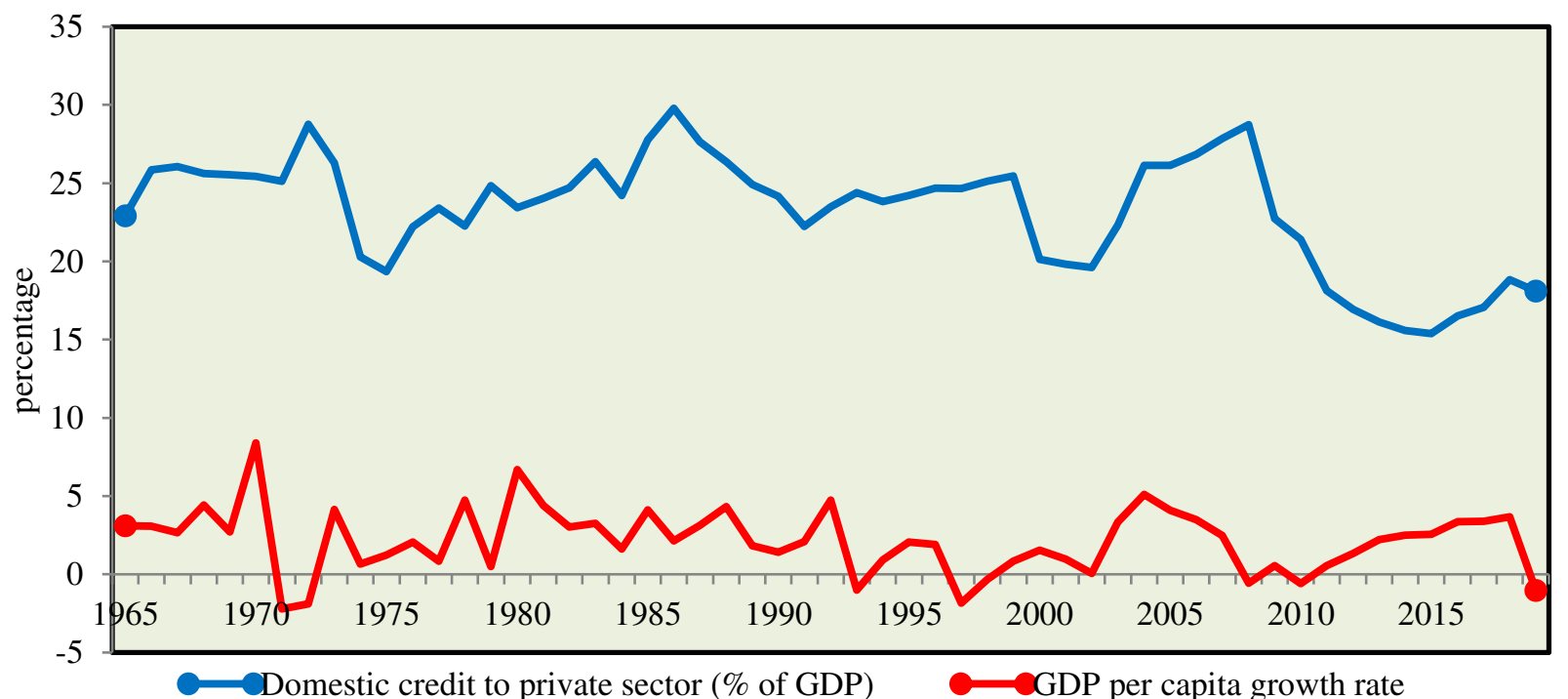

Figure 3: Trends in financial development and GDP per capita growth rates (1965-2019)

Source: World Development Indicators (World Bank 2020) 
161 In this section, we first summarize the existing studies which have scrutinized the energy consumption-economic 162 growth nexus. Then, we summarize the studies which have documented evidence regarding the impacts of natural gas use on economic growth. Lastly, we summarize the studies on financial development and economic growth.

\subsection{The literature on energy consumption and economic growth}

In general, the aggregate energy consumption-economic growth nexus has been causally analyzed under four hypotheses: growth, conservation, feedback, and neutrality hypotheses (Ozturk, 2010; Ozcan\& Ozturk, 2019). Firstly, the growth hypothesis refers to the phenomenon that energy consumption stimulates economic growth. Secondly, the conservation hypothesis refers to economic growth influencing the energy consumption levels; thus, this hypothesis advocates in favor of conserving energy for future use. Thirdly, the feedback hypothesis refers to economic growth and energy use being interdependent; thus, implicating that these variables influence one another. Lastly, the neutrality hypothesis asserts that there is no causal relationship between economic growth and energy consumption. The existing studies have evaluated the energy consumption-economic growth nexusthrough the prism of these four hypotheses using both panel and time-series data.However, traditionally the aggregate energy consumption levels were used to evaluate the impacts of energy use on growth. In a relevant study on Sub-Saharan African countries, Akinlo (2008) found evidence of the feedback hypothesis holding for the cases of Gambia, Ghana, and Senegal, the conservation hypothesis for Sudan and Zimbabwe, and the neutrality hypothesis for Cameroon, Cote D'Ivoire, Nigeria, Togo, and Kenya. In other country-specific studies, Odhiambo (2009) andTang et al. (2016)reported that the growth hypothesis holds for Tanzania andVietnam, respectively. As far as panel data evidence is concerned, Ouedraogo (2013) considered the Economic Community of West African States (ECOWAS) and found that economic growth causally influences the energy consumption level in the short-run while energy consumption influences economic growth in the long-run.

Besides, cleaner energy use is said to play a central role in facilitating environmental well-being and therefore sustaining economic growth, whereby researchers have emphasized the importance of investing in clean energy development projects (Ma et al., 2021). Therefore, keeping into consideration the contrasting impacts of clean and unclean energy use on economic growth, several of the existing studies have also disaggregated the energy consumption-economic growth analysis by isolating the effects of non-renewable and renewable energy consumption on economic growth. Inglesi-Lotz (2016) claimed that a rise in the renewable energy consumption level and its share in the total energy consumption level contribute to higher economic growth in the case of a panel of Organization for Economic Cooperation and Development (OECD) countries. Recently, Shahbaz et al. (2020) used data from 38 high-renewable energy-consuming countries and found high levels of renewable energy use resulting in higher levels of economic growth. Similar results were found in another study on 29 OECD countries by Gozgor et al. (2018). Besides, the authors also asserted that non-renewable energy consumption also stimulates growth in these selected OECD nations.In another study by Ivanovski et al. (2021), the authors argued that both renewable and non-renewable energy consumption stimulate economic growth in non-OECD countries but in the context of the OECD nation, only non-renewable energy consumption was evidenced to facilitate economic growth. Recently, in the context of Vietnam, Ha and Ngoc (2020) verified a bidirectional association between non-renewable energy consumption and economic growth. Apart from isolating the impacts of non-renewable and renewable energy use on economic growth, several of the existing studies have further disaggregated the energy consumptioneconomic growth analysis by scrutinizing the growth impacts associated with different non-renewable and energy renewable resources. Since this current study is interested in examining the natural gas consumption-economic growth nexus, only the preceding studies in this regard are summarized in the next sub-section. 
There is a limited amount of analysis on the relationship between natural gas consumption and economic growth in the literature. Usually, the research on the causal relationships between natural gas use and economic growth can be separated into two sections. A time-series data study (Shahbaz et al., 2013; Siddiqui, 2004; Solarin \& Shahbaz, 2015) was performed in the first literature collection. The second comparatively smaller collection of literature based on panel data model analysis (Apergis \& Payne, 2010; Asghar, 2008; Melike E. Bildirici \& Bakirtas, 2014; Fatai, Oxley, \& Scrimgeour, 2004; Furuoka, 2016; Hossein, Yazdan, \& Ehsan, 2012; Kum, Ocal, \& Aslan, 2012; Ozturk \& Al-Mulali, 2015; Pirlogea, 2012). Some of them have used a set of co-integration tools, for example (Gregory \& Hansen, 1996; Hansen \& Seo, 2002; Søren Johansen, 1988; Soren Johansen \& Juselius, 1990; Pesaran, Shin, \& Smith, 2001a; Robert \& Granger, 1987)to scrutinize the relationship without a causal analysis (Adeniran, 2009; Hu \& Lin, 2008; Işik, 2010a; Khan \& Ahmad, 2008; Shahbaz et al., 2013; Shahiduzzaman \& Alam, 2014). Consequently, the assumptions made in relationship with the presence of natural gas-led production or else become debatable. Even so, the co-integration test only shows the existence of causality but ignores the direction. Unexpectedly, only a few of the preceding studies have conducted cointegration analysis (Granger, Hasaio, Toda, and Yamamoto) to examine the causative relationship between the use of natural gas and economic expansion (Apergis \& Payne, 2010; Melike E. Bildirici \& Bakirtas, 2014; Das, McFarlane, \& Chowdhury, 2013; Hossein et al., 2012; Işik, 2010b; Kum et al., 2012; Lee \& Chang, 2005; Pirlogea, 2012; Siddiqui, 2004; Yang, 2000).

In a study by Galadima\&Aminu (2020), the authors claimed that natural gas consumption boosts economic growth in Nigeria. Besides, the authors verified this claim using non-linear estimation techniques and concluded that the natural gas consumption-economic growth nexus is non-linear.Similarly in the context of African nations, Awodumi and Adewuyi (2020) found that increasing natural gas consumption is not only effective in enhancing economic growth in Gabon but is also efficient in mitigating environmental pollution. However, in the context of Nigeria, natural gas consumption was argued to exhibit growth-inhibitory impacts. On the other hand, in the context of Egypt, the authors stated that natural gas consumption exerts negligible economic growth impacts. In another study on the Group of Seven (G7) countries, Kum et al. (2012) opined that natural gas consumption influences economic growth for the case of Italy but in the context of the United Kingdom economic growth was found to causally influence the natural gas consumption level. Besides, for Germany, the United States, and France natural gas and economic growth were found to causally influence one another.

Ozturk and Al-Mulali (2015), in the context of selected Gulf Cooperation Council (GCC) countries, stated that promoting natural gas consumption can be an effective means of boosting the economic growth levels of the countries of concern. Moreover, the causality findings revealed a bi-directional causal association between natural gas use and economic growth. In a country-specific analysis in the context of Tunisia, Farhani et al. (2014) concluded that natural gas consumption enhances economic growth. Similarly, Heidari et al. (2013) recommended liberalization of natural gas prices to facilitate higher consumption of natural gas in Iran which, in turn, was claimed to be necessary for stimulating the growth of the Iranian economy. On the other hand, considering the gross capital formation as an indicator of economic growth, Etokakpan et al. (2020) stated that natural gas consumption and economic growth are mutually influenced; thus, a feedback relationship was ascertained. Table 1 summarizes the other relevant country-specific and panel studies, including Pakistan, that have shredded light on the relationship between natural gas consumption and economic growth.

Table 1: Literature review (2015-2020) regarding natural gas consumption and economic growth

\begin{tabular}{|c|c|c|c|c|}
\hline Author & Country & Variable & Method & Finding \\
\hline \multicolumn{5}{|c|}{ Country-specific studies } \\
\hline $\begin{array}{l}\text { (Shahbaz } \\
\text { et al., } \\
\text { 2013) }\end{array}$ & Pakistan & NGC,GDP,Labur,Capital,Export & $\begin{array}{l}\text { ARDL, Johansen, } \\
\text { Decomposition } \\
\text { variance }\end{array}$ & Growth \\
\hline (Siddiqui, & Pakistan & NGC, RGDP & ARDL & Neutrality \\
\hline
\end{tabular}




\begin{tabular}{|c|c|c|c|c|}
\hline (Aqeel \& & Pakistan & GC, RGDP & Egle and Granger, & Neutrality \\
\hline 2001) & & & $\begin{array}{l}\text { Hsiao,s granger } \\
\text { causality }\end{array}$ & \\
\hline $\begin{array}{l}\text { (Khan \& } \\
\text { Ahmad, } \\
\text { 2008) }\end{array}$ & Pakistan & RGDP, CPI, NGC & ARDL & $\begin{array}{l}\text { Co- } \\
\text { integration }\end{array}$ \\
\hline $\begin{array}{l}\text { (Hassan, } \\
\text { Tahir, } \\
\text { Wajid, } \\
\text { Mahmoo }\end{array}$ & Pakistan & GDP,NGC,L,C & $\begin{array}{l}\text { Johansen maximum } \\
\text { likelihood }\end{array}$ & Growth \\
\hline $\begin{array}{l}\mathrm{d}, \& \\
\text { Farooq, } \\
\text { 2018) }\end{array}$ & & & Granger causality & \\
\hline $\begin{array}{l}\text { (Shahbaz, } \\
\text { Arouri, \& } \\
\text { Teulon, } \\
\text { 2014) }\end{array}$ & Pakistan & NGC,GDP,Labur,Capital & ARDL, & $\begin{array}{l}\text { Complemen } \\
\mathrm{t}\end{array}$ \\
\hline & & & Causality test & \\
\hline $\begin{array}{l}\text { (Erdoğan, } \\
\text { Gedikli, } \\
\text { \& Kirca, } \\
\text { 2019) }\end{array}$ & Turkey & GDP, NGC & Causality test & $\begin{array}{l}\text { Unidirection } \\
\text { al }\end{array}$ \\
\hline $\begin{array}{l}\text { (Farhani } \\
\& \\
\text { Rahman, }\end{array}$ & France & NG,C,L,GDP & Granger causality & Feedback \\
\hline $\begin{array}{l}2019) \\
\text { (Solarin } \\
\& \\
\text { Shahbaz, } \\
\text { 2015) }\end{array}$ & Malaysia & FDI,NGC,GDP,TO & ARDL & Feedback \\
\hline \multicolumn{5}{|c|}{ Panel studies } \\
\hline $\begin{array}{l}\text { (Aydin, } \\
2018)\end{array}$ & $\begin{array}{l}\text { Ten } \\
\text { natural } \\
\text { gas- } \\
\text { consumi } \\
\text { ng } \\
\text { countries }\end{array}$ & GDP,NG,GCF,TO & Granger causality & Growth \\
\hline $\begin{array}{l}\text { (Chang et } \\
\text { al., 2015) }\end{array}$ & G7 & GDP, NG & Granger causality & Neutrality \\
\hline $\begin{array}{l}\text { (Destek, } \\
\text { 2016) }\end{array}$ & $\begin{array}{l}26- \\
\text { OECD }\end{array}$ & GDP,GCF,NGC,TO & $\begin{array}{l}\text { FMOLS,DOLS,VE } \\
\text { CM }\end{array}$ & Feedback \\
\hline $\begin{array}{l}\text { (Fadiran, } \\
\text { Adebusu } \\
\text { yi, \& } \\
\text { Fadiran, } \\
\text { 2019) }\end{array}$ & 12-Euro & GDP,GCF,NG,L,TO & VECM & $\begin{array}{l}\text { Conservativ } \\
\text { e }\end{array}$ \\
\hline
\end{tabular}




\begin{tabular}{|c|c|c|c|c|}
\hline $\begin{array}{l}\text { (Furuoka, } \\
2016)\end{array}$ & $\begin{array}{l}\text { China, } \\
\text { Japan }\end{array}$ & GDP,NGC,GCF,Export & ARDL & Growth \\
\hline $\begin{array}{l}\text { (Jahangir } \\
\text { \& Dural, } \\
\text { 2018) }\end{array}$ & $\begin{array}{l}\text { Caspian } \\
\text { Sea } \\
\text { region }\end{array}$ & $\begin{array}{l}\text { COEX,COP,COPRO,COR,GDP,NGEX,NGP,NGPR } \\
\text { O,NGR }\end{array}$ & $\begin{array}{l}\text { OLS, Granger } \\
\text { causality }\end{array}$ & $\begin{array}{l}\text { Unidirection } \\
\text { al }\end{array}$ \\
\hline $\begin{array}{l}\text { (Solarin } \\
\& \\
\text { Ozturk, } \\
2016)\end{array}$ & $\begin{array}{l}\text { 12- } \\
\text { OPEC }\end{array}$ & GDP, NG & Granger causality & Feedback \\
\hline $\begin{array}{l}\text { (Zhi- } \\
\text { Guo, } \\
\text { Cheng, \& } \\
\text { Dong- } \\
\text { Ming, } \\
\text { 2018) }\end{array}$ & $\begin{array}{l}\text { Northeas } \\
\text { t Asia }\end{array}$ & C,L,NG,GDP & Causality test & $\begin{array}{l}\text { One-way } \\
\text { relation }\end{array}$ \\
\hline
\end{tabular}

A significant preponderance of research indicates that the financial sector's growth plays a crucial role in economic growth. It stimulates economic development through capital accumulation and technological development by accelerating savings, rallying and accumulating savings, and generating investment information. Goldsmith (1969) was the first one to prove the clear connection between financial growth and per capita GDP empirically. One reason for this positive relationship is that financial intermediation enhances productivity before increasing investment(Bencivenga \& Smith, 1991; Greenwood \& Jovanovic, 1990). Many studies provided evidence that there is a positive relationship between financial development indicators and economic growth(Beck \& Levine, 2004; Beck, Levine, \& Loayza, 2000; King \& Levine, 1993; Levine, 1997, 2003; Rajan \& Zingales, 1998).In a recent study on Sub-Saharan African nations, Junior Abeka (2021) concluded that economic growth in these African countries is conditional on the development of their respective financial sectors. Besides, the authors also emphasized that information and communications technology enhances the favorable growth impacts associated with financial development in Africa.In another study on Brazil, Russia, India, China, and South Africa (BRICS), Raghutla and Chittedi (2020) also asserted financial development exerts positive economic growth effects on these emerging economies. Conversely, as opposed to the findings of the abovementioned studies, Kapaya (2020) argued that financial development is yet to be effective in boosting economic growth in Tanzania; rather the financial development policies have hampered the growth of the Tanzanian economy. Similarly, Raheem et al. (2020) also found evidence of financial development dampening growth in the case of the G7 countries. While all thesestudies emphasize the linear relationship between financial and economic development, several studies have also scrutinized the nonlinearity of this nexus. Few studies indicate that financial development has a positive relationship with economic growth for values above the threshold(Deidda \& Fattouh, 2002; Rioja \& Valev, 2004), whereas others document inverse results (Arcand, Berkes, \& Panizza, 2015; Cecchetti \& Kharroubi, 2012; Ergungor, 2008; Law \& Singh, 2014; Shen \& Lee, 2006). Apart from directly contributing to economic growth, several studies have also claimed that financial development improves environmental quality which, in turn, can indirectly help to sustain the economic growth performances (Qin et al., 2021). 
The dataset in the current study includes the data on annual GDP, natural gas consumption, and financial development in the context of Pakistan.

The GDP figures are the annual total market value of the goods and services produced within Pakistanfor each year between 1965 and 2019. The natural gas consumption figures areannual volumes of natural gas consumed for different purposes within the Pakistan economy.Lastly, financial development is proxied by the domestic credits extended by the commercial banks as a percentage share in the GDP of Pakistan for the respective year. Table 2 shows theunits of measurement and corresponding data sources of these variables.

Table 2. Variables and sources

\begin{tabular}{llll}
\hline Variables & Units & Sources & References \\
\hline GDP & United States dollars & World Development Indicators & (Shahbaz et al., 2013) \\
& & BP Statistical Review of World & \\
NGC & Billion cubic meters & Energy & (Solarin \& Ozturk, 2016) \\
FD & $\%$ of GDP & World Development Indicators & (Neog \& Yadava, 2020) \\
\hline
\end{tabular}

3.2. Empirical model

Following Neog\&Yavada (2020), we model the economic growth of Pakistan as a function of natural gas consumption and financial development which can be shown as:

$$
\ln G D P p c_{t}=f\left(\ln N G C_{t}, F D_{t}\right)
$$

Equation 1 can be specified in its linear form as:

$$
\ln G D P p c_{t}=\beta_{0}+\beta_{1} \ln N G C_{t}+\beta_{2} F D_{t}+\mu_{t}(2)
$$

where the subscript $t$ refers to the time period considered in this study $(t=1965,1966, \ldots, 2019)$. In equation (2), GDPpc refers to the gross domestic product per capita (used to proxy for economic growth in Pakistan), NGC stands for natural gas consumption level, and FD is the percentage share of credit extended to the private sector in the GDP of Pakistan (used to proxy for financial development). The parameters $\beta=\left(\beta_{0}, \beta_{1}, \beta_{2}\right)$ are the parameters to be estimated. The variables GDP and NGC are transformed into their natural logarithms to predict the elasticity parameters.

According to the conventional econometric methodology, the long-term and short-term links between two or more variables are determined using the ARDL error-correction model. This estimation technique considers the linear association among the variables and ignores the non-linearity aspect. Contemplating the recent non-linear existence of the variables, Shin et al. (2014) expanded the ARDL bounds testing cointegration technique of Pesaran et al. (1999; 2021b)and introduced the asymmetrical ARDL cointegration method. This approach is competentin displaying short-run volatilities and asymmetries. The specific asymmetric long-run equation of our empirical model (Equation 2) can be shown as:

$$
\ln G D P p c_{t}=a_{0}+a_{1} \ln N G C_{t}^{+}+a_{2} \ln N G C_{t}^{-}+a_{3} F D_{t}^{+}+a_{4} F D_{t}^{-}+\varepsilon_{t}
$$

In equation (3), $N G C_{t}^{+}, N G C_{t}^{-}, F D_{t}^{+}$and,$F D_{t}^{-}$are the positive and negative shock components of natural gas consumption and financial development,respectively:

$$
\left\{\begin{array}{l}
N G C_{i}^{+}=\sum_{i=1}^{t} \Delta N G C_{i}^{+}=\sum_{i=1}^{t} \operatorname{MAX}\left(\Delta N G C_{i}, 0\right) \\
N G C_{i}^{-}=\sum_{i=1}^{t} \Delta N G C_{i}^{-}=\sum_{k=1}^{t} \operatorname{MIN}\left(\Delta N G C_{i}, 0\right)
\end{array}\right.
$$




$$
\left\{\begin{array}{l}
F D_{i}^{+}=\sum_{i=1}^{t} \Delta F D_{i}^{+}=\sum_{i=1}^{t} \operatorname{MAX}\left(\Delta F D_{i}, 0\right) \\
F D_{i}^{-}=\sum_{i=1}^{t} \Delta F D_{i}^{-}=\sum_{i=1}^{t} \operatorname{MIN}\left(\Delta F D_{i}, 0\right)
\end{array}(5)\right.
$$

Following the Equation (2), in the NARDL model can be specified as:

$$
\begin{gathered}
\Delta \ln G D P p c_{t}=\beta_{0}+\beta_{1} \ln G D P p c_{t-1}+\beta_{2} \ln N G C_{t-1}^{+}+\beta_{3} \ln N G C_{t-1}^{-}+\beta_{4} F D_{t-1}^{+}+\beta_{5} F D_{t-1}^{-}+ \\
\sum_{i=1}^{m} \delta_{1 i} \Delta \ln G D P p c_{t-1+} \sum_{i=1}^{n} \delta_{2 i} \Delta \ln N G C_{t-1}^{+}+\sum_{i=1}^{p} \delta_{3 i} \Delta \ln N G C_{t-1}^{-}+\sum_{i=1}^{q} \delta_{4 i} \Delta F D_{t-1}^{+}+ \\
\sum_{i=1}^{r} \delta_{5 i} \Delta F D_{t-1}^{-}+\mu_{i}(6)
\end{gathered}
$$

In equation (6), we put $\mathrm{m}, \mathrm{n}, \mathrm{p}, \mathrm{q}$, and $\mathrm{r}$ as lags orders. But, $\beta_{1}, \beta_{2}, \beta_{3}, \beta_{4}$, and $\beta_{5}$ represent long-term positive and negative coefficient effects of NGC and FD on GDP per capita. $\sum_{i=1}^{n} \delta_{2 i}, \sum_{i=1}^{p} \delta_{3 i}, \sum_{i=1}^{q} \delta_{4 i}$ and $\sum_{i=1}^{r} \delta_{5 i}$ consider the short-run positive and negative impacts of NGC and FD on GDP, correspondingly. In this paper, by applying the NARDL technique, the non-linear long-run link is captured.

\subsection{Econometric methodology}

The econometric analysis begins by checking for the order of integration among the variables. It is important to check this order because both ARDL and NARDL methods can handle variables integrated at either level, I(0), or first difference, I(1), but not second difference, I(2). This model has only one drawback since it cannot proceed in event of the variables being integrated at second (Ibrahim, 2015). Hence, firstly we apply the Augmented DickeyFuller (ADF) and Phillips-Perron (PP) root unit tests. However, since these tests cannot control for the structural break issues within the estimation process, weuse the Zivot-Andrews (1992) unit root with structural break test to ascertain the integrating properties of the variables. The unit root analysis is followed by the cointegration analysis. In the next step, we evaluate the cointegration among the variables as a pre=requisite to predicting the long-run coefficients. In this regard, we use the bounds test to check whether cointegration occurs. Besides, to check for the cointegrating properties by accommodating the structural break issue within the estimation process, weuse the Gregory-Hansen (1996) cointegration test.

After checking that co-integration, we apply the NARDL approach to predict the effects of positive and negative shocks to natural gas consumption and financial development $\left(N G C_{t}^{+}, N G C_{t}^{-}, F D_{t}^{+}\right.$, and $\left.F D_{t}^{-}\right)$on economic growth in Pakistan. The nonlinear effects of a $1 \%$ change in the $N G C_{t}^{+}, N G C_{t}^{-}, F D_{t}^{+}$and $F D_{t}^{-}$are assessed respectively as:

$$
\begin{gathered}
\left\{\begin{array}{l}
S_{h}^{+}(\ln N G C)=\sum_{j-0}^{h} \frac{\partial \ln G D P p c_{t+1}}{\partial \ln N G C_{t-1}^{+}}(7) \\
S_{h}^{-}(\ln N G C)=\sum_{j-0}^{h} \frac{\partial \ln G D P p c_{t+1}}{\partial \ln N G C_{t-1}^{-}}
\end{array}\right. \\
\left\{\begin{array}{l}
S_{h}^{+}(F D)=\sum_{j-0}^{h} \frac{\partial \ln G D P p c_{t+1}}{\partial F D_{t-1}^{+}} \\
S_{h}^{-}(F D)=\sum_{j-0}^{h} \frac{\partial L \ln G D P p c_{t+1}}{\partial F D_{t-1}^{-}}
\end{array}\right.
\end{gathered}
$$

Lastly, we apply the Hacker-Hatemi-J (2012) causality test to predict the causal relationships between the variables of concern. Figure 4 illustrates the econometric methodology considered in this study. 


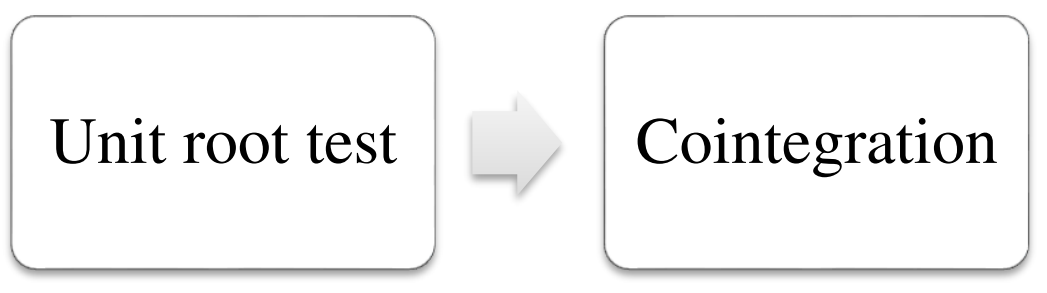

\section{Empirical results}

The summary statistics of the variables are presented in Table 3. It can be seen that all three variables are negatively skewed and also platykurtic. Besides, the Jarque-Bera statistics showthe normality of the distribution of the variables.

Table 3: Summary statistics

\begin{tabular}{lccc}
\hline Descriptive statistics & lnGDPpc & lnNGC & FD \\
\hline Mean & 4.022 & 1.036 & 22.877 \\
Median & 4.026 & 1.042 & 23.823 \\
Maximum & 5.243 & 1.659 & 29.786 \\
Minimum & 2.743 & 0.169 & 15.305 \\
Std. Dev. & 0.777 & 0.438 & 3.607 \\
Skewness & -0.242 & -0.232 & -0.408 \\
Kurtosis & 1.787 & 1.862 & 2.396 \\
Jarque-Bera & 3.388 & 3.463 & 2.362 \\
Probability & 0.183 & 0.176 & 0.306 \\
Observations & 55 & 55 & 55 \\
\hline
\end{tabular}

Figure 4: Econometric methodological framework

The ARDL model can handle variables that are stationary at either level or first difference or both. Hence, the ADF, PP, and Zivot-Andrews unit root tests were used and the results of the three tests are shown in Table 4. The unit root findings, both considering and not considering structural break issues, reveal that all the variables are not stationary at $\mathrm{I}(0)$ but stationary at the $\mathrm{I}(1)$; thus, it is verified that none of the variables is stationary at $\mathrm{I}(2)$. Therefore, the NARDL technique can be applied.The unit root analysis is followed by the cointegration analysis.

Table 4: Unit root test results

\begin{tabular}{llll}
\hline Variable & ADF & PP & Zivot-Andrews \\
\hline
\end{tabular}




\begin{tabular}{lcccccc}
\hline Considering Break & \multicolumn{2}{c}{ No } & \multicolumn{2}{c}{ No } & \multicolumn{2}{c}{ Yes } \\
\hline & $\mathrm{I}(0)$ & $\mathrm{I}(1)$ & $\mathrm{I}(0)$ & $\mathrm{I}(1)$ & $\mathrm{I}(0)$ & $\mathrm{I}(1)$ \\
\cline { 2 - 7 } $\operatorname{lnGDPpc}$ & -0.653 & $-6.302^{* * *}$ & -0.653 & $-6.279^{* * *}$ & $-4.190(1993)$ & $-8.830^{* * *(1991)}$ \\
$\operatorname{lnNGC}$ & -2.547 & $-5.140^{* * *}$ & -2.247 & $-4.996^{* * *}$ & $-4.230(2006)$ & $-5.690^{* * *}(2003)$ \\
FD & -1.923 & $-6.258^{* * *}$ & -2.150 & $-6.224 * * *$ & $-4.126(2011)$ & $-7.279^{* * *}(2009)$ \\
\hline
\end{tabular}

Note: The locations of the structural breaks from the Zivot-Andrews analysis are given in the parentheses. *** denotes statistical significance at $1 \%$ level.

For the ARDL bounds test, we calculate equation (6) using a general-to-specific method and alphabets $\mathrm{p}=\mathrm{q}=2$ as the optimal lag period. This groundbreaking method was also accompanied by (Shin et al., 2014)to finalize the asymmetrical ARDL model. According to the general-to-specific technique, we include only the significant lagged repressors because insignificant lagged regressors can interfere in dynamic multipliers(Katrakilidis \& Trachanas, 2012).Additionally, we also perform the Gregory-Hansen test to account for the structural break issue within the cointegration analysis. The cointegration test results are reported in Table 5. From the estimated F-statistic from the bounds test, we can see that the value of the F-statistic is above the lower and upper bound critical values at $1 \%$ levels of significance. Thus, the null hypothesis of non-cointegration is rejected to affirm cointegrating relationships between economic growth, natural gas consumption, and financial development in Pakistan. Similarly, the statistical significance of the $\mathrm{ADF}, \mathrm{Zt}$, and $\mathrm{Za}$ statistics from the Gregory-Hansen test also affirm the presence of cointegrating equations in the model. Hence, it can be said that economic growth in Pakistan has long-run associations with natural gas consumption and financial development level. Consequently, the NARDL analysis is conducted to ascertain the long-run elasticities of economic growth.

Table 5: Cointegration test results

\begin{tabular}{|c|c|c|c|}
\hline \multicolumn{4}{|c|}{ Panel A: Bounds test } \\
\hline Equation & F-stat. & & \\
\hline $\operatorname{lnGDPpc}=\mathrm{f}(\operatorname{lnNGC,FD)}$ & $15.066 * * *$ & & \\
\hline Critical values & Upper bound, I(1) & Upper bound, I(1) & \\
\hline $10 \%$ & 2.2 & 3.09 & \\
\hline $5 \%$ & 2.56 & 3.49 & \\
\hline $2.50 \%$ & 2.88 & 3.87 & \\
\hline $1 \%$ & 3.29 & 4.37 & \\
\hline \multicolumn{4}{|c|}{ Panel B: Gregory-Hansen test (with structural break) } \\
\hline Equation & ADF stat. & Zt stat. & Za stat. \\
\hline $\operatorname{lnGDPpc}=\mathrm{f}(\ln N G C, \mathrm{FD})$ & $-7.35 * * *(1991)$ & $-7.41 * * *(1991)$ & $-59.66 * *$ \\
\hline
\end{tabular}
denote statistical significance at $1 \%$ and $5 \%$ level, respectively.

Table 6presents the short- and long-term asymmetric relationships between the variables of concern. In the shortrun, only a positive shock to natural gas consumption is seen to boost economic growth in Pakistan. The elasticity estimate shows that a $1 \%$ change in positive shock to natural gas consumption would account for a $0.11 \%$ rise in Pakistan's per capita GDP figures in the short-run. Besides, the negative shocks to natural gas consumption are found to be ineffective in influencing the economic growth level in the short-run. Similarly, both positive and negative shocks to financial development are seen to be ineffective in affecting the economic growth level of Pakistan in the short-run. On the other hand, in the long-run, apositive shock tothe natural gas consumption level boosts Pakistan's per capita economic growth level. The elasticity estimate shows that a $1 \%$ change in positive shock to natural gas consumption would account for a $0.198 \%$ rise in Pakistan's per capita GDP figures.Alternatively, negative shocks tothe natural gasconsumption level are found to dampen economic growth in Pakistan. The 
corresponding elasticity parameter denotes that a $1 \%$ rise in the negative shock to natural gas consumption level would account for a decline in the per capita GDP level by $0.818 \%$. Therefore, these findings imply that natural gas is a major determinant of growth for Pakistan whereby the nation needs to ensure a sufficient supply of natural gas to sustain its growth achievements in the future. Our results are in line with Shahbaz et al. (2013), Solarin \& Ozturk (2016). On the other hand, the elasticity estimates also reveal that positive shocks to the financial development figures inhibit economic growth in Pakistan. A rise in the positive shock to the share of credit extended to the private sector in the GDP accounts for a decline in the per capita GDP figures of Pakistan by $0.004 \%$. Similarly, negative shocks to the financial development level also dampen the growth figures of Pakistan. A $1 \%$ rise in the negative shocks to the share of credit extended to the private sector in the GDP triggers a decline in the per capita GDP level by $0.001 \%$. Hence, it can be said that the relationship between economic growth and financial development in the context of Pakistan is non-linear.

Table 6: Long-run results from the NARDL analysis

\begin{tabular}{llc}
\hline Variable & Short-run & Long-run \\
\hline LnNGC_POS & $0.105^{*}$ & $0.198^{* * *}$ \\
LnNGC_NEG & 0.500 & $0.818^{* * *}$ \\
FD_POS & -0.001 & $-0.004 * * *$ \\
FD_NEG & 0.005 & $0.002 * * *$ \\
D(1991) & $-1.160^{* * *}$ & $-1.709 * * *$ \\
C & $0.133 * * *$ & $0.390 * * *$ \\
\hline
\end{tabular}

Note: *** denotes statistical significance at $1 \%$ level; The variable $\mathrm{D}(1991)$ is the dummy variable that accounts for the structural break location identified from the cointegration analysis.

The presence of asymmetries among natural gas consumption, economic growth,and financial developmentareverifiedusing the Wald test. The corresponding outcomes from the Wald Test areshown in Table 7. The results show the asymmetries between the variables used in this study. The results indicate that the impact of natural gas consumption and financial development followed the asymmetric relationship.

Table 7: Asymmetric results

\begin{tabular}{lll}
\hline Variable & Wald stat. & P-value \\
\hline lnGDPpc and lnNGC & $4.114^{* * *}$ & 0.000 \\
$\operatorname{lnGDPpc}$ and FD & $3.510^{* * *}$ & 0.000 \\
\hline
\end{tabular}

Note: $* * *$ denotes statistical significance at $1 \%$ level.

We have further investigated some necessary diagnostic tests, such as normality of residual, serial correlation, and heteroskedasticity. The corresponding results, as shown in Table 8, indicate that there are no autocorrelation issues in our model since the estimated LM statistic is statistically insignificant. Besides, the Ramsey RESET test statistic confirms that the model is well-specified. On the other hand, the outcome from the ARCH tests suggests that there are no heteroscedasticity concerns either. Furthermore, the J-B normality test finding shows that the residuals are normally distributed. At the same time, the stability of the predicted elasticity parameters is checked using the Cumulative Sum of Squares (CUSUM) and Cumulative Sum of Squares Squared (CUSUMSQ) tests. The outcomes, as illustrated in Figure 5, confirm the stability of the estimated results from the NARDL analysis.

Table 8: Diagnostic tests results 


\begin{tabular}{lcc} 
Test & Statistics & Prob. \\
\hline LM & 1.401341 & 0.4963 \\
J-B & 4.881434 & 0.2997 \\
ARCH & 0.120277 & 0.7287 \\
RESET & 1.007128 & 0.3206 \\
\hline
\end{tabular}

422

423
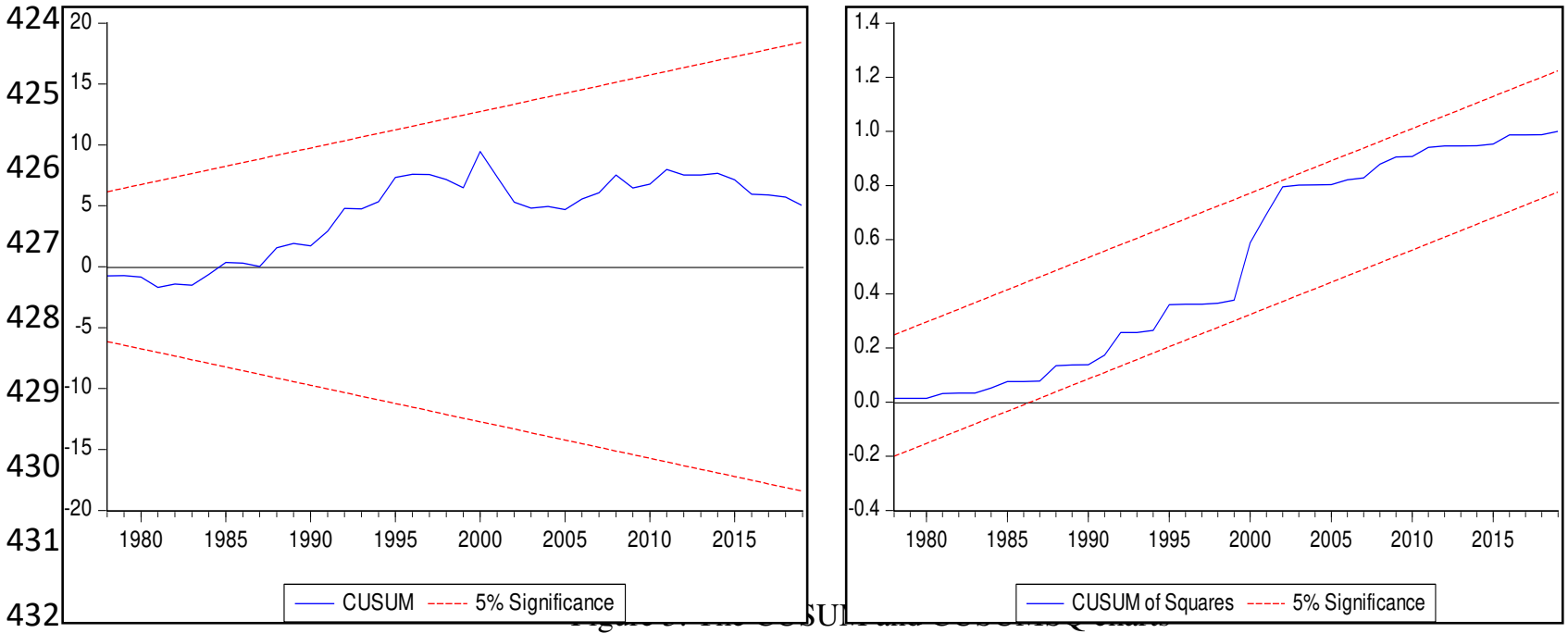

433

434 Finally, the Hacker-Hatemi-J causality test is performed to evaluate the causal associations. The causality results, as reported in Table 9, reveal unidirectional causality running from natural gas consumption to the per capita GDP level in Pakistan. On the other hand, no causal relationship between economic growth and financial development could be established from the causality analysis.

Table 9: The causality test results

\begin{tabular}{cccccc}
\hline Null Hypothesis & MWALD stat. & \multicolumn{3}{c}{ Critical values } & Decision \\
\cline { 3 - 6 } & & $1 \%$ & $5 \%$ & $10 \%$ & \\
\hline LnNGC $\rightarrow \operatorname{lnGDPpc}$ & $8.334^{* * *}$ & 7.455 & 4.120 & 2.879 & Unidirectional causality between lnNCG to \\
$\ln$ GDPpc $\rightarrow \ln N G C$ & 2.145 & 7.320 & 4.100 & 2.840 & lnGDppc \\
FD $\rightarrow \ln$ GDPpc & 2.550 & 7.298 & 4.150 & 2.850 & No causality between lnGDPpc and FD \\
$\operatorname{lnGDPpc} \rightarrow$ FD & 2.140 & 7.410 & 4.161 & 2.888 & \\
\hline
\end{tabular}

Note: $\rightarrow$ denotes does not Granger cause. $* * *$ denotes statistical significance at $1 \%$ level.

5. Conclusion and policy implications

441 Ensuring energy security is pertinent for sustaining economic growth, especially in the context of the developing nations which are largely energy-starved. Besides, these countries are also overwhelmingly reliant on fossil fuels for generating the national output. However, given the associated environmental concerns, it is recommended that developing nations enhance the consumption of relatively cleaner energy resources. Against this background, this study aimed to evaluate the asymmetric impacts of natural gas consumption and financial development on Pakistan's economic growth over the 1965-2019 period. The findings from the cointegration analysis confirmed long-run associations between economic growth, natural gas consumption, and financial development in Pakistan. The 
NARDL estimates revealed that in the short-run only positive shocks to natural gas consumption level positively affect the per capita GDP level of Pakistan. On the other hand, in the long-run, positive and negative shocks to natural consumption levels are found to increase and decrease the per capita GDP level of Pakistan, respectively. On the other hand, both positive and negative shocks to financial development were found to inhibit the growth of the Pakistan economy. Furthermore, the causality estimates validate the growth hypothesis by verifying a unidirectional causality stemming from natural gas consumption to economic growth. In line with these findings, several policy suggestions can be put forward.

Firstly, the government should adopt policies to enhance the natural gas extraction rates to increase the indigenous natural gas supplies. Additionally, it is also pertinent to invest in projects for the development of technology that is required to enhance the natural gas extraction rates. Furthermore, keeping both economic and environmental sustainability into consideration, the government should incentivize the private sector to invest in the energy sector, especially for enhancing the share of natural gas-fired electricity output in Pakistan's total electricity output figures. Secondly, the government needs to restructure the existing financial development policies in order to phase out the associated growth-inhibitory impacts. Ideally, it is essential for enhancing access to credit for the private investors who are keen to invest in high-growth-contributing sectors. Simultaneously, greater provision for credit should be introduced for the private sector to come forward to invest in the energy sector, especially to enhance the natural gas supplies. This would not only facilitate the growth of the Pakistan economy but would also indirectly enhance growth by boosting the natural gas consumption level.

Data limitation was the only constraint faced in conducting this study. Consequently, relevant variables could not be included in the model. Besides, this current study can be extended in several ways. First, the present paper can be extended to include other dependent variables like $\mathrm{CO} 2$ emission, renewable energy production and consumption, trade openness and technical factors, etc. to assess the impacts of natural gas consumption and financial development on these macroeconomic variables. Second, panel studies can be conducted in the context of South Asian countries including Pakistan. Third, different econometric techniques can be applied for a robustness check of the findings from this study.

\section{Declarations}

-Ethical Approval: Not applicable

-Consent to Participate: Not applicable

-Consent to Publish: Not applicable

-Funding: Funding was received for this study from the National Social Science Fund of China under the grant (19BGL057).

-Competing Interests: The authors declare that they have no competing interests.

-Availability of data and materials: The data sets used during the current study are available from the corresponding author on reasonable request.

-Authors Contributions: HMS conceptualized, conducted the econometric analysis and wrote the introduction. ZL conceptualized, conducted the econometric analysis and supervised the work. MM analyzed the findings, conducted the literature review, wrote the conclusions and recommendations and compiled the overall manuscript.RA analyzed the findings and wrote the conclusions and recommendations.HM reviewed the literature, discussed the findings, and edited the entire draft.

\section{References}

Adeniran, O. (2009). Does energy consumption cause economic growth? An empirical evidence from Nigeria. University of Dundee, UK. 
Abbasi, K. R., Shahbaz, M., Jiao, Z., \& Tufail, M. (2021). How energy consumption, industrial growth, urbanization, and $\mathrm{CO} 2$ emissions affect economic growth in Pakistan? A novel dynamic ARDL simulations approach. Energy, 221, 119793.

Akinlo, A. E. (2008). Energy consumption and economic growth: Evidence from 11 Sub-Sahara African countries. Energy Economics, 30(5), 2391-2400.

Apergis, N., \& Payne, J. E. (2010). Natural gas consumption and economic growth: A panel investigation of 67 countries. Applied Energy, 87(8), 2759-2763. doi:10.1016/j.apenergy.2010.01.002

Aqeel, A., \& Butt, M. S. (2001). The relationship between energy consumption and economic growth in Pakistan. Asia-Pacific Development Journal, 8(2), 101-110.

Arcand, J. L., Berkes, E., \& Panizza, U. (2015). Too much finance? Journal of Economic Growth, 20(2), $105-148$.

Asghar, Z. (2008). Energy-GDP relationship: a causal analysis for the five countries of South Asia. Applied Econometrics and International Development, 8(1).

Awan, A. M., Azam, M., Saeed, I. U., \& Bakhtyar, B. (2020). Does globalization and financial sector development affect environmental quality? A panel data investigation for the Middle East and North African countries. Environmental Science andPollution Research, 27(36), 45405-45418.

Awodumi, O. B., \& Adewuyi, A. O. (2020). The role of non-renewable energy consumption in economic growth and carbon emission: Evidence from oil producing economies in Africa. Energy Strategy Reviews, 27, 100434.

Aydin, M. (2018). Natural gas consumption and economic growth nexus for top 10 natural GasConsuming countries: A granger causality analysis in the frequency domain. Energy, 165, 179186. doi:10.1016/j.energy.2018.09.149

Banks, F. E. (2003). An introduction to the economics of natural gas. OPEC review, 27(1), 25-63.

Beck, T., \& Levine, R. (2004). Stock markets, banks, and growth: Panel evidence. Journal of Banking andFinance, 28(3), 423-442.

Beck, T., Levine, R., \& Loayza, N. (2000). Finance and the Sources of Growth. Journal of Financial Economics, 58(1-2), 261-300.

Bencivenga, V. R., \& Smith, B. D. (1991). Financial intermediation and endogenous growth. The review of economic studies, 58(2), 195-209.

Bildirici, M. E., \& Bakirtas, T. (2014). The relationship among oil, natural gas and coal consumption and economic growth in BRICTS (Brazil, Russian, India, China, Turkey and South Africa) countries. Energy, 65, 134-144. doi:10.1016/j.energy.2013.12.006

Bildirici, M. E., \& Turkmen, C. (2015). Nonlinear causality between oil and precious metals. Resources Policy, 46, 202-211.

Cecchetti, S. G., \& Kharroubi, E. (2012). Reassessing the impact of finance on growth (No. 381). Bank for international settlements.

Chandio, A. A., Jiang, Y., \& Rehman, A. (2019). Energy consumption and agricultural economic growth in Pakistan: is there a nexus?. International Journal of Energy Sector Management. https://doi.org/10.1108/IJESM-08-2018-0009

Chang, T., Gupta, R., Inglesi-Lotz, R., Masabala, L. S., Simo-Kengne, B. D., \& Weideman, J. P. (2015). The causal relationship between natural gas consumption and economic growth: evidence from the G7 countries. Applied Economics Letters, 23(1), 38-46. doi:10.1080/13504851.2015.1047085

Çoban, O., Yorganc1la, F. N., \& Çoban, A. (2018). Relationship between renewable energy consumption and sustainable economic growth: the case of Turkey. Paper presented at the 2018 International Conference and Utility Exhibition on Green Energy for Sustainable Development (ICUE).

Das, A., McFarlane, A. A., \& Chowdhury, M. (2013). The dynamics of natural gas consumption and GDP in Bangladesh. Renewable and Sustainable Energy Reviews, 22, 269-274.

Deidda, L., \& Fattouh, B. (2002). Non-linearity between finance and growth. Economics Letters, 74(3), 339-345. 
Destek, M. A. (2016). Natural gas consumption and economic growth: Panel evidence from OECD countries. Energy, 114, 1007-1015. doi:10.1016/j.energy.2016.08.076

Dong, K., Sun, R., Li, H., \& Liao, H. (2018). Does natural gas consumption mitigate CO2 emissions: testing the environmental Kuznets curve hypothesis for 14 Asia-Pacific countries. Renewable and Sustainable Energy Reviews, 94, 419-429.

Erdoğan, S., Gedikli, A., \& Kırca, M. (2019). A note on time-varying causality between natural gas consumption and economic growth in Turkey. Resources Policy, 64. doi:10.1016/j.resourpol.2019.101504

Ergungor, O. E. (2008). Financial system structure and economic growth: Structure matters. International Review of Economics and

Finance, 17(2), 292-305.

Etokakpan, M. U., Solarin, S. A., Yorucu, V., Bekun, F. V., \& Sarkodie, S. A. (2020). Modeling natural gas consumption, capital formation, globalization, $\mathrm{CO} 2$ emissions and economic growth nexus in Malaysia: Fresh evidence from combined co-integration and causality analysis. Energy Strategy Reviews, 31. doi:10.1016/j.esr.2020.100526

Fadiran, G., Adebusuyi, A. T., \& Fadiran, D. (2019). Natural gas consumption and economic growth: Evidence from selected natural gas vehicle markets in Europe. Energy, 169, 467-477. doi:10.1016/j.energy.2018.12.040

Fareed, Z., Meo, M. S., Zulfiqar, B., Shahzad, F., \& Wang, N. (2018). Nexus of tourism, terrorism, and economic growth in Thailand: new evidence from asymmetric ARDL co-integration approach. Asia Pacific Journal of Tourism Research, 23(12), 1129-1141.

Farhani, S., \& Rahman, M. M. (2019). Natural gas consumption and economic growth nexus: an investigation for France. International Journal of Energy Sector Management, 14(2), 261-284. doi:10.1108/ijesm-07-2019-0005

Fatai, K., Oxley, L., \& Scrimgeour, F. G. (2004). Modelling the causal relationship between energy consumption and GDP in New Zealand, Australia, India, Indonesia, The Philippines and Thailand. Mathematics and Computers in Simulation, 64(3-4), 431-445.

Furuoka, F. (2016). Natural gas consumption and economic development in China and Japan: An empirical examination of the Asian context. Renewable and Sustainable Energy Reviews, 56, 100-115. doi:10.1016/j.rser.2015.11.038

Farhani, S., Shahbaz, M., Arouri, M., \& Teulon, F. (2014). The role of natural gas consumption and trade in Tunisia's output. Energy Policy, 66, 677-684.

Gregory, A. W., \& Hansen, B. E. (1996). Residual-based tests for cointegration in models with regime shifts. Journal of econometrics, 70(1), 99-126.

Gozgor, G., Lau, C. K. M., \& Lu, Z. (2018). Energy consumption and economic growth: New evidence from the OECD countries. Energy, 153, 27-34.

Galadima, M. D., \& Aminu, A. W. (2020). Nonlinear unit root and nonlinear causality in natural gaseconomic growth nexus: Evidence from Nigeria. Energy, 190, 116415.

Goldsmith, R. W. (1969). Financial structure and development. Retrieved from

Greenwood, J., \& Jovanovic, B. (1990). Financial development, growth, and the distribution of income. Journal of political Economy, 98(5, Part 1), 1076-1107.

Gregory, A. W., \& Hansen, B. E. (1996). Residual-based tests for co-integration in models with regime shifts. Journal of econometrics, 70(1), 99-126.

Hansen, B. E., \& Seo, B. (2002). Testing for two-regime threshold co-integration in vector errorcorrection models. Journal of econometrics, 110(2), 293-318.

Hassan, M. S., Tahir, M. N., Wajid, A., Mahmood, H., \& Farooq, A. (2018). Natural gas consumption and economic growth in Pakistan: production function approach. Global Business Review, 19(2), 297-310. 
Ha, N. M., \& Ngoc, B. H. (2020). Revisiting the relationship between energy consumption and economic growth nexus in Vietnam: new evidence by asymmetric ARDL cointegration. Applied Economics Letters. https://doi.org/10.1080/13504851.2020.1789543

Hacker, S., \& Hatemi-J, A. (2012). A bootstrap test for causality with endogenous lag length choice: theory and application in finance. Journal of Economic Studies, 39(2), 144-160.

Heidari, H., Katircioglu, S. T., \& Saeidpour, L. (2013). Natural gas consumption and economic growth: Are we ready to natural gas price liberalization in Iran?. Energy policy, 63, 638-645.

Hussain, I., \& Rehman, A. (2021). Exploring the dynamic interaction of CO2 emission on population growth, foreign investment, and renewable energy by employing ARDL bounds testing approach. Environmental Science and Pollution Research, 1-11.

Hossein, A., Yazdan, G. F., \& Ehsan, A. G. (2012). The relationship between energy consumption, energy prices and economic growth: case study (OPEC countries). OPEC Energy review, 36(3), 272-286.

Hu, J.-L., \& Lin, C.-H. (2008). Disaggregated energy consumption and GDP in Taiwan: a threshold cointegration analysis. Energy Economics, 30(5), 2342-2358.

Işik, C. (2010a). Natural gas consumption and economic growth in Turkey: a bound test approach. Energy Systems, 1(4), 441-456.

Işik, C. (2010b). Natural gas consumption and economic growth in Turkey: a bound test approach. Energy Systems, 1(4), 441-456. doi:10.1007/s12667-010-0018-1

Inglesi-Lotz, R. (2016). The impact of renewable energy consumption to economic growth: A panel data application. Energy economics, 53, 58-63.

Irfan, M., Zhao, Z. Y., Ikram, M., Gilal, N. G., Li, H., \& Rehman, A. (2020a). Assessment of India's energy dynamics: Prospects of solar energy. Journal of Renewable and Sustainable Energy, 12(5), 053701. https://doi.org/10.1063/1.5140236

Irfan, M., Zhao, Z. Y., Panjwani, M. K., Mangi, F. H., Li, H., Jan, A., ... \& Rehman, A. (2020b). Assessing the energy dynamics of Pakistan: prospects of biomass energy. Energy Reports, 6, 8093. https://doi.org/10.1016/j.egyr.2019.11.161

Irfan, M., Zhao, Z. Y., Rehman, A., Ozturk, I., \& Li, H. (2021). Consumers' intention-based influence factors of renewable energy adoption in Pakistan: a structural equation modeling approach. Environmental Science and Pollution Research, 28(1), 432-445. https://doi.org/10.1007/s11356-020-10504-w

Ivanovski, K., Hailemariam, A., \& Smyth, R. (2021). The effect of renewable and non-renewable energy consumption on economic growth: Non-parametric evidence. Journal of Cleaner Production, 286, 124956.

Jahangir, S. M. R., \& Dural, B. Y. (2018). Crude oil, natural gas, and economic growth: impact and causality analysis in Caspian Sea region. International Journal of Management and Economics, 54(3), 169-184. doi:10.2478/ijme-2018-0019

Johansen, S. (1988). Statistical analysis of co-integration vectors. Journal of economic dynamics

control, 12(2-3), 231-254.

Johansen, S., \& Juselius, K. (1990). Maximum likelihood estimation and inference on co-integrationwith appucations to the demand for money. Oxford Bulletin of Economics and statistics, 52(2), 169-210.

Junior Abeka, M., Andoh, E., Gatsi, J. G., \& Kawor, S. (2021). Financial development and economic growth nexus in SSA economies: The moderating role of telecommunication development. Cogent Economics \& Finance, 9(1), 1862395.

Katrakilidis, C., \& Trachanas, E. (2012). What drives housing price dynamics in Greece: New evidence from asymmetric ARDL co-integration. Economic Modelling, 29(4), 1064-1069.

Kapaya, S. M. (2020). Financial development and economic growth in Tanzania: an ARDL and bound testing approach. Asian Journal of Economics and Banking. https://doi.org/10.1108/AJEB-092020-0063 
Kum, H., Ocal, O., \& Aslan, A. (2012). The relationship among natural gas energy consumption, capital and economic growth: Bootstrap-corrected causality tests from G-7 countries. Renewable and Sustainable Energy Reviews, 16(5), 2361-2365.

Khan, M. A., \& Ahmad, U. (2008). Energy demand in Pakistan: a disaggregate analysis. The Pakistan Development Review, 437-455.

King, R. G., \& Levine, R. (1993). Finance and growth: Schumpeter might be right. The quarterly journal of economics, 108(3), 717-737.

Kum, H., Ocal, O., \& Aslan, A. (2012). The relationship among natural gas energy consumption, capital and economic growth: Bootstrap-corrected causality tests from G-7 countries. Renewable and Sustainable Energy Reviews, 16(5), 2361-2365.

Law, S. H., \& Singh, N. (2014). Does too much finance harm economic growth? Journal of Banking and

Finance, 41, 36-44.

Latief, R., \& Lefen, L. (2019). Foreign direct investment in the power and energy sector, energy consumption, and economic growth: Empirical evidence from pakistan. Sustainability, 11(1), 192.

Li, Z. Z., Li, R. Y. M., Malik, M. Y., Murshed, M., Khan, Z., \& Umar, M. (2021). Determinants of carbon emission in China: how good is green investment?. Sustainable Production and Consumption, 27, 392-401. https://doi.org/10.1016/j.spc.2020.11.008

Lee, C.-C., \& Chang, C.-P. (2005). Structural breaks, energy consumption, and economic growth revisited: evidence from Taiwan. Energy Economics, 27(6), 857-872.

Levine, R. (1997). Financial development and economic growth: views and agenda. Journal of economic literature, 35(2), 688-726.

Levine, R. (2003). More on finance and growth: more finance, more growth? Review-Federal Reserve Bank of Saint Louis, 85(4), 31-46.

Ma, Q., Murshed, M., \& Khan, Z. (2021). The nexuses between Energy Investments, Technological Innovations, R\&D Expenditure, Emission Taxes, Tertiary sector development, and Carbon Emissions in China: A roadmap to achieving carbon-neutrality. Energy Policy, 155, 112345. https://doi.org/10.1016/j.enpol.2021.112345

Magazzino, C., Mele, M., \& Schneider, N. (2021). A D2C algorithm on the natural gas consumption and economic growth: Challenges faced by Germany and Japan. Energy, 219, 119586.

Nathaniel, S.P., Murshed, M., \& Bassim, M. (2021). The nexus between economic growth, energy use, international trade and ecological footprints: the role of environmental regulations in N11 countries. Energy, Ecology \& Environment. https://doi.org.10.1007/s40974-020-00205-y

Neog, Y., \& Yadava, A. K. (2020). Nexus among CO2 emissions, remittances, and financial development: a NARDL approach for India. Environmental Science and

Pollution Research, 27(35), 44470-44481.

Ouattara, B. (2004). Modelling the long run determinants of private investment in Senegal. Retrieved from

Ozturk, I. (2010). A literature survey on energy-growth nexus. Energy Policy, 38(1), 340-349.

Ozturk, I., \& Al-Mulali, U. (2015). Natural gas consumption and economic growth nexus: Panel data analysis for GCC countries. Renewable and Sustainable Energy Reviews, 51, 998-1003.

Odhiambo, N. M. (2009). Energy consumption and economic growth nexus in Tanzania: An ARDL bounds testing approach. Energy policy, 37(2), 617-622.

Ouedraogo, N. S. (2013). Energy consumption and economic growth: Evidence from the economic community of West African States (ECOWAS). Energy economics, 36, 637-647. 
Ozcan, B., \& Ozturk, I. (2019). Renewable energy consumption-economic growth nexus in emerging countries: A bootstrap panel causality test. Renewable and Sustainable Energy Reviews, 104, 3037.

Ozturk, I., \& Al-Mulali, U. (2015). Natural gas consumption and economic growth nexus: Panel data analysis for GCC countries. Renewable and Sustainable Energy Reviews, 51, 998-1003.

Payne, J. E. (2010). A survey of the electricity consumption-growth literature. Applied Energy, 87(3), 723-731.

Percebois, J. (2008). The supply of natural gas in the European Union-strategic issues. OPEC Energy review, 32(1), 33-53.

Pesaran, M. H., Shin, Y., \& Smith, R. J. (2001a). Bounds testing approaches to the analysis of level relationships. Journal of applied econometrics, 16(3), 289-326.

Pesaran, M. H., Shin, Y., \& Smith, R. J. (2001b). Bounds testing approaches to the analysis of level relationships. Journal of applied econometrics, 16(3), 289-326.

Pesaran, M. H., Shin, Y., \& Smith, R. P. (1999). Pooled mean group estimation of dynamic heterogeneous panels. Journal of the American statistical Association, 94(446), 621-634.

Pirlogea, C. C., Claudiu. (2012). Econometric perspective of the energy consumption and economic growth relation in European Union. Renewable and Sustainable Energy Reviews, 16(8), 57185726.

Qin, L., Raheem, S., Murshed, M., Miao, X., Khan, Z., \& Kirikkaleli, D. (2021). Does financial inclusion limit carbon dioxide emissions? Analyzing the role of globalization and renewable electricity output. Sustainable Development. https://doi.org/10.1002/sd.2208

Rajan, R., \& Zingales, L. (1998). Financial development and growth. American Economic Review, 88(3), 559-586.

Raghutla, C., \& Chittedi, K. R. (2020). Financial development, real sector and economic growth: Evidence from emerging market economies. International Journal of Finance \& Economics. https://doi.org/10.1002/ijfe.2114

Raheem, I. D., Tiwari, A. K., \& Balsalobre-Lorente, D. (2020). The role of ICT and financial development in CO 2 emissions and economic growth. Environmental Science and Pollution Research, 27(2), 1912-1922.

Rehman, A., \& Deyuan, Z. (2018a). Pakistan's energy scenario: a forecast of commercial energy consumption and supply from different sources through 2030. Energy, sustainability and society, 8(1), 1-5. https://doi.org/10.1186/s13705-018-0167-y

Rehman, A., \& Deyuan, Z. (2018b). Investigating the linkage between economic growth, electricity access, energy use, and population growth in Pakistan. Applied sciences, 8(12), 2442. https://doi.org/10.3390/app8122442

Rehman, A., Deyuan, Z., Chandio, A. A., \& Hussain, I. (2018). An empirical analysis of rural and urban populations' access to electricity: evidence from Pakistan. Energy, Sustainability and Society, 8(1), 1-9. https://doi.org/10.1186/s13705-018-0183-y

Rehman, A., Irfan, M., Hena, S., \& Chandio, A. A. (2019b). By applying an ARDL bounds testing approach and causality test to investigate the electricity consumption and production with economic growth. World Journal of Science, Technology and Sustainable Development, 17(2), 182-199. https://doi.org/10.1108/WJSTSD-08-2019-0054

Rehman, A., Ma, H., Ozturk, I., Ahmad, M., Rauf, A., \& Irfan, M. (2020a). Another outlook to sectorlevel energy consumption in Pakistan from dominant energy sources and correlation with economic growth. Environmental Science and Pollution Research. https://doi.org/10.1007/s11356-020-09245-7

Rehman, A., Ma, H., Ozturk, I., Murshed, M., Chishti, M.Z., \& Dagar, V. (2021). The dynamic impacts of $\mathrm{CO} 2$ emissions from different sources on Pakistan's economic progress: a roadmap to 
sustainable environment. Environment, Development and Sustainability. http://doi.org/10.1007/s10668-021-01418-9

Rehman, A., Rauf, A., Ahmad, M., Chandio, A. A., \& Deyuan, Z. (2019a). The effect of carbon dioxide emission and the consumption of electrical energy, fossil fuel energy, and renewable energy, on economic performance: evidence from Pakistan. Environmental Science and Pollution Research, 26(21), 21760-21773. https://doi.org/10.1007/s11356-019-05550-y

Rehman, A., Zhang, D., Chandio, A. A., \& Irfan, M. (2020b). Does electricity production from different sources in Pakistan have dominant contribution to economic growth? Empirical evidence from long-run and short-run analysis. The Electricity Journal,33(3), 106717. https://doi.org/10.1016/j.tej.2020.106717

Rehman, A., Ma, H., Ozturk, I., Murshed, M., Chishti, M.Z., \& Dagar, V. (2021). The dynamic impacts of $\mathrm{CO} 2$ emissions from different sources on Pakistan's economic progress: a roadmap to sustainable environment. Environment, Development and Sustainability. https://doi.org/10.1007/s10668-021-01418-9

Rioja, F., \& Valev, N. (2004). Does one size fit all?: a reexamination of the finance and growth relationship. Journal of development Economics, 74(2), 429-447.

Robert, F. E., \& Granger, C. W. (1987). Co-integration and error correction: Representation, estimation, and testing. Econometrica, 55(2), 251-276.

Shahbaz, M., Arouri, M., \& Teulon, F. (2014). Short-and long-run relationships between natural gas consumption and economic growth: Evidence from Pakistan. Economic Modelling, 41, 219-226.

Shahbaz, M., Lean, H. H., \& Farooq, A. (2013). Natural gas consumption and economic growth in Pakistan. Renewable and Sustainable Energy Reviews, 18, 87-94. doi:10.1016/j.rser.2012.09.029

Shahbaz, M., Raghutla, C., Chittedi, K. R., Jiao, Z., \& Vo, X. V. (2020). The effect of renewable energy consumption on economic growth: Evidence from the renewable energy country attractive index. Energy, 207, 118162.

Shahiduzzaman, M., \& Alam, K. (2014). A reassessment of energy and GDP relationship: the case of Australia. Environment, development and

sustainability, 16(2), 323-344.

Shen, C.-H., \& Lee, C.-C. (2006). Same financial development yet different economic growth: why? Journal of Money, Credit and

Banking, 1907-1944.

Shin, Y., Yu, B., \& Greenwood-Nimmo, M. (2014). Modeling asymmetric co-integration and dynamic multipliers in a nonlinear ARDL framework. In Festschrift in honor of Peter Schmidt (pp. 281314): Springer.

Siddiqui, R. (2004). Energy and economic growth in Pakistan. The Pakistan Development Review, 175200.

Solarin, S. A., \& Ozturk, I. (2016). The relationship between natural gas consumption and economic growth in OPEC members. Renewable and Sustainable Energy Reviews, 58, 1348-1356. doi:10.1016/j.rser.2015.12.278

Solarin, S. A., \& Shahbaz, M. (2013). Trivariate causality between economic growth, urbanisation and electricity consumption in Angola: Cointegration and causality analysis. Energy Policy, 60, 876884.

Solarin, S. A., \& Shahbaz, M. (2015). Natural gas consumption and economic growth: The role of foreign direct investment, capital formation and trade openness in Malaysia. Renewable and Sustainable Energy Reviews, 42, 835-845. doi:10.1016/j.rser.2014.10.075

Tang, C. F., Tan, B. W., \& Ozturk, I. (2016). Energy consumption and economic growth in Vietnam. Renewable and Sustainable Energy Reviews, 54, 1506-1514.

World Bank. (2020). The World Development Indicators. The World Bank. 
$\mathrm{Xu}$, B., \& Lin, B. (2019). Can expanding natural gas consumption reduce China's CO2 emissions?. Energy Economics, 81, 393-407.

Xue, L., Haseeb, M., Mahmood, H., Alkhateeb, T. T. Y., \& Murshed, M. (2021). Renewable energy use and ecological footprints mitigation: evidence from selected South Asian economies. Sustainability, 13(4), 1613. https://doi.org/10.3390/su13041613

Yang, H.-Y. (2000). A note on the causal relationship between energy and GDP in Taiwan. Energy Economics, 22(3), 309-317.

Zhi-Guo, L., Cheng, H., \& Dong-Ming, W. (2018). Empirical research on the relationship between natural gas consumption and economic growth in the Northeast Asia. Energy \& Environment, 29(2), 216-231. doi:10.1177/0958305x17745273

790 Zivot, E., \& Andrews, D. W. K. (2002). Further evidence on the great crash, the oil-price shock, and the unit-root hypothesis. Journal of business \& economic statistics, 20(1), 25-44. 